\title{
7
}

\section{Health, Livelihood and Well-Being in the Coastal Delta of Bangladesh}

Mohammed Mofizur Rahman and Sate Ahmad

\subsection{Introduction}

Bangladesh contains one of the largest, most densely populated and heavily farmed deltas of the world which is at great risk of increased flooding and submergence from sea-level rise (Chap. 3; Syvitski et al. 2009). Coastal Bangladesh is a focus for national and international research due to the diverse ecosystem services it provides along with the invaluable natural resources it carries_-such as coral reef, fisheries, forest resourcesand it includes the world's largest contiguous mangrove forest (Hoque and Datta 2005; Hossain 2001). Approximately 14 million or ten per cent of the total population of Bangladesh live in the south-west coastthe study area. Living in the delta means living on an ever-changing

M. M. Rahman ( $\bowtie)$

International Center for Diarrheal Disease Research, Bangladesh (icddr,b), Dhaka, Bangladesh

S. Ahmad

Faculty of Agricultural and Environmental Sciences, University of Rostock, Rostock, Germany 


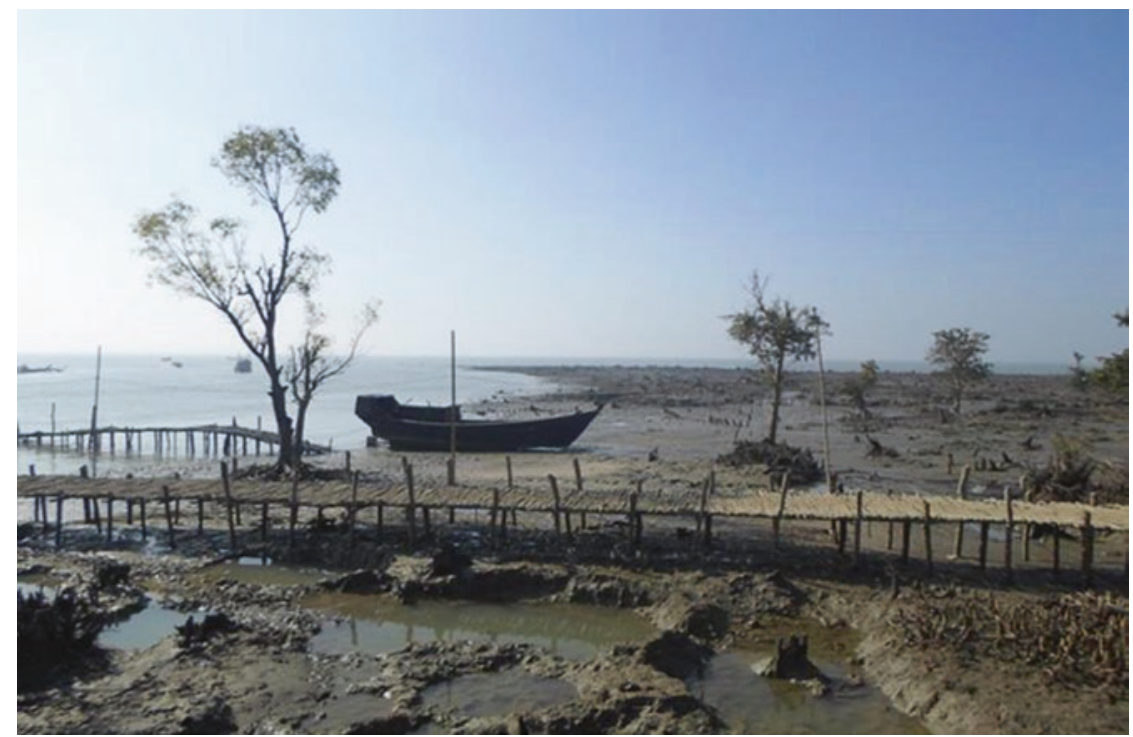

Fig. 7.1 The ever-changing coast of Bangladesh (Photograph: Mohammed Mofizur Rahman)

balance between land and sea (see Fig. 7.1) and fresh and saline water (van Schendel 2009). To meet the demands of such a large population, high levels of exploitation of natural resources and degradation of the environment have occurred (Hossain 2001).

The social and economical vulnerability of the south-west coast is due to its exposure to severe natural hazards. Amidst existing vulnerabilities, climate change is likely to impact human health directly or indirectly (Shahid 2009). Direct effects on health may be caused by extreme weather events such as cyclones (Shultz et al. 2005) and slow onset hazards such as salinity intrusion in soil, groundwater and surface water (Khan et al. $2011,2014)$. Health is also indirectly influenced through changes in air pollution, spread of disease vectors, food and water insecurity, undernutrition, displacement, changes in livelihoods and through infliction of mental ill-health (Haque et al. 2012, Kabir et al. 2016; Nahar et al. 2014). 


\subsection{Coastal Livelihoods and Relation to Health}

Coastal Bangladesh offers a diverse range of livelihoods including coastal and marine fisheries, aquaculture (e.g. shrimp, crab culture), agriculture and forest resource harvesting. Besides these, other economic activities in the south-west coast include salt production, fish processing (e.g. dry-fish production) (Fig. 7.2), day labour, as well as tourism (mainly in the Sundarbans and Kuakata).

While it has been increasingly recognised that ill-health contributes to poverty by diminishing people's meagre resources (spent on health), it is rarely acknowledged that people often are not able to gain access to health services if they cannot mobilise vital livelihood resources (Obrist et al. 2007).

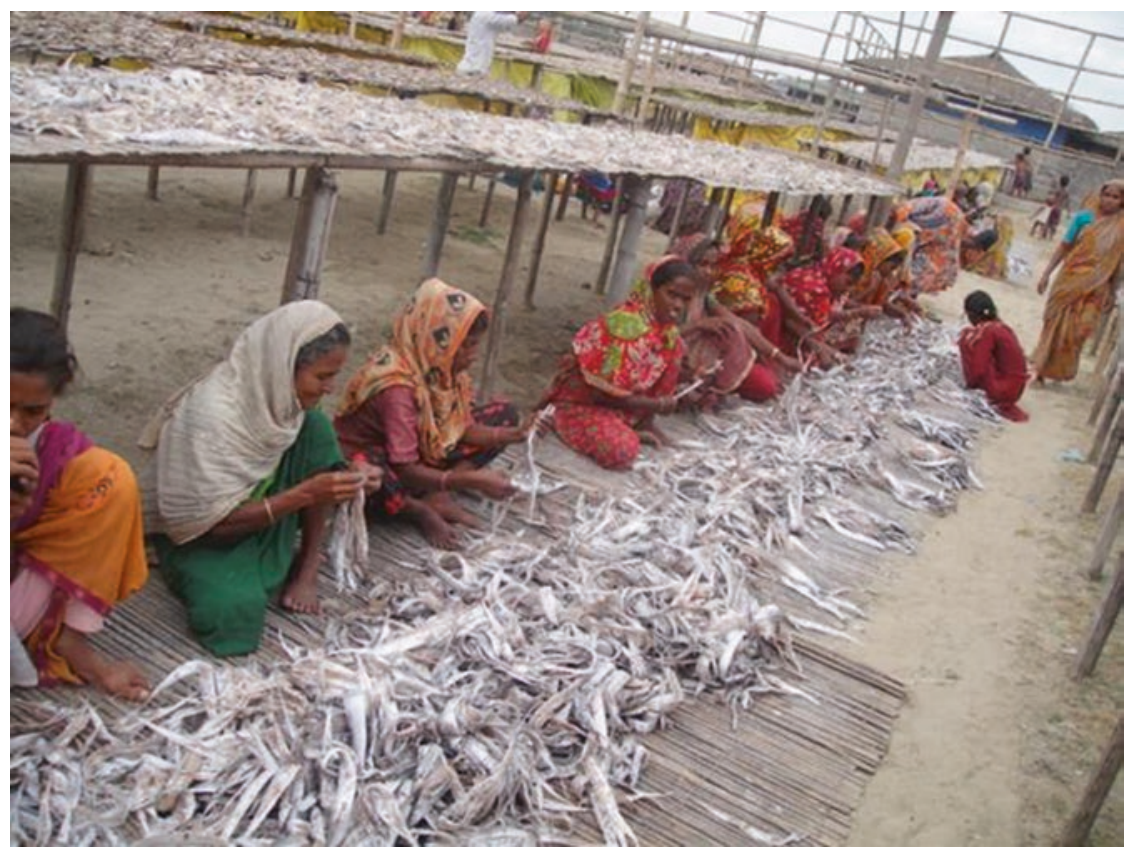

Fig. 7.2 Thousands of people are engaged in fish drying activities, especially women and children (Photograph: Mohammed Mofizur Rahman) 
As such, health and livelihoods are interdependent; change in one is likely to change the status of the other. In the context of coastal regions, physical isolation may make some communities highly dependent on ecosystem services, thereby reducing their access to alternative livelihoods (Pomeroy et al. 2006). This can make them especially vulnerable to environmental shocks or change (e.g. salinity intrusion in coastal waters and soil). In addition coastal areas are also prone to land-use changes such as transformation from rice cultivation to shrimp culture (Ali 2006). Such changes may result in loss of livelihoods of local people (Deb 1998), thereby causing impoverishment, debt and the associated lack of access to healthcare. Moreover, poverty may affect health also by reducing people's entitlement sets needed to acquire food and thus resulting in undernourishment (Osmani 1993) (Fig. 7.3). Local environmental change may also result in a change in livelihoods and in some cases may influence migration decision making. Thus, this may have implications for the health and nutrition of such migrants at the destination.

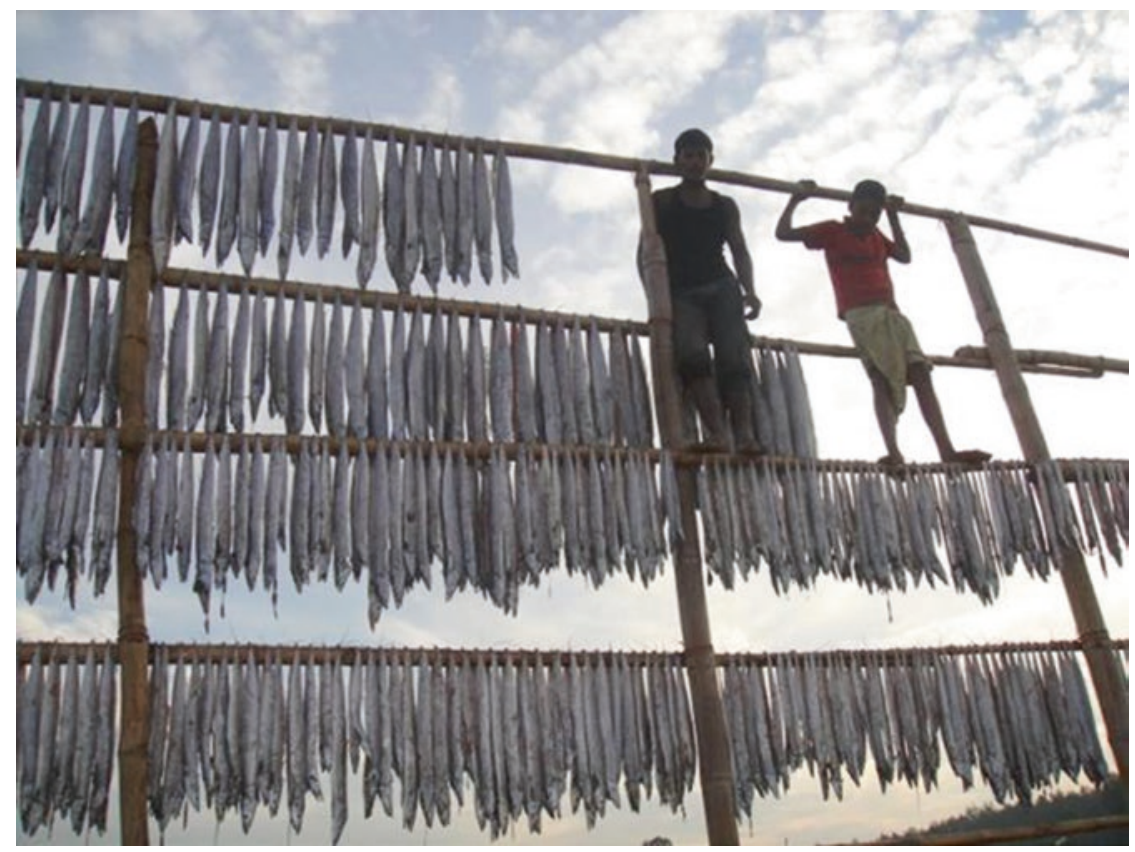

Fig. 7.3 Dry fish is a relatively inexpensive source of protein in coastal Bangladesh (Photograph: Mohammed Mofizur Rahman) 


\subsection{Food Security and Nutrition in Relation to Health}

The tide dominated coastal delta of Bangladesh is exposed to a wide variety of environmental stresses. These include rapid onset hazards such as storm surge, cyclones, river and coastal erosion as well as slow onset hazards such as salinity intrusion in groundwater as well as in surface water. Such hazards not only have direct impacts on mortality and morbidity but also may pose a threat to food security through the loss of arable land and agricultural crops and through loss of livelihoods (Shameem et al. 2014).

Food security plays an important role in the understanding of health and well-being (Jaron and Galal 2009). It is a prerequisite to good health as undernourishment and malnutrition are widely agreed to be the results of hunger and food insecurity. Undernourishment of mothers may result in low birth weight (Kramer 1987), while malnutrition of infants may inhibit brain growth and subsequent intellectual development (Stoch and Smythe 1963). Additionally, food security is a significant determinant of child growth in rural Bangladesh (Saha et al. 2009) as well as throughout the world (Frongillo et al. 1997).

Bangladesh has progressed significantly towards reducing food insecurity. However, despite this progress, domestic food production is increasingly unable to meet the demand of consumers for a more diverse diet which, in turn, has led to increasing food imports since 2006 (HKI and BIGH 2016). Food availability itself may not result in food security, and thus access to food is another important factor to take into account. According to the Food Security Nutritional Surveillance Project (FSNSP), as compared to the rest of the country, the coastal belt shows seasonality in household food insecurity, with highest prevalence (39 per cent of households in 2014) occurring during the monsoon season. Prevalence of food insecurity for the coastal belt is the second highest in comparison to other surveillance zones, second only to the northern charlands of Bangladesh (HKI and BIGH 2016) and significantly higher than the national average level of 23-26 per cent (in 2014) according to the same surveillance project. 


\subsection{Water and Health}

In coastal Bangladesh, drinking water sources mostly include tube-wells of various depth, but also rainwater, rivers, canals and ponds. The community has access to different water sources depending on geographical availability, income and weather conditions (Scheelbeek 2015). These different sources have varying levels of sodium bacterial contamination and arsenic risk (Houghton 2009). Storage containers can also act as breeding grounds for mosquitoes and bacteria, which favour warmer waters, increasing risk of diarrhoeal disease. Saline tolerant mosquitoes have also been discovered which has implications on the risk from malaria and dengue (Yunus et al. 2011).

Salinity is an additional major problem in coastal waters, which has only recently come to light in the literature, with respect to its implications on health outcomes. As most of the population in south-west coastal Bangladesh depend on groundwater as the primary source of drinking water, salinity intrusion into coastal aquifers may have serious consequences on human health. Several studies have found that the levels of sodium in drinking water are much above the WHO standards (Khan et al. 2011). Salt is a well-known trigger of hypertension. Recent studies have raised concern over the increased risk of hypertension from exposure to salinity in coastal Bangladesh (Vineis et al. 2011) and additionally have found an association between drinking water salinity and high blood pressure (Talukder et al. 2017).

Increased salinity exposure through drinking, cooking and bathing has also reported to have potential links with skin diseases, acute respiratory infection, cardio-vascular diseases, strokes and diarrhoeal diseases (Vineis et al. 2011; Khan et al. 2011). Maternal health may also be impacted by increased exposure to salinity as it was found to be significantly associated with increased risk of (pre)eclampsia and gestational hypertension in south-west coastal Bangladesh (Khan et al. 2014).

A major cause for concern is that a positive feedback mechanism may exist whereby saline water consumption increases thirst leading to higher fluid intake, which if saline may result in even higher levels of thirst (Islam et al. 2011). 


\subsection{Health Risks from Natural Hazards}

Bangladesh ranks fifth in the WorldRiskIndex for disaster risk related to natural disasters in 2016 (Comes et al. 2016). Around 26 per cent of the population are affected by cyclones, while 70 per cent live in flood-prone regions (Cash et al. 2013). The coastal delta is particularly vulnerable to cyclones and tidal surges owing to its low elevation (Chap. 8). Other hazards that the coastal area is exposed to include coastal and river erosion and water logging from polders.

Since the 1950s changes in extreme weather events have been observed (IPCC 2014). In Bangladesh weather and extreme weather were found to be associated with mortality (Lindeboom et al. 2012). In Abhoynagar, a rural coastal sub-district of Bangladesh, it was found that heavy rainfall was associated with mortality (Lindeboom et al. 2012).

Extreme precipitation events and higher temperatures are likely to cause widespread food-borne and water-borne disease outbreaks including cholera and other diarrheal diseases. Cholera (Vibrio cholerae) outbreaks have been shown to be linked to rising sea surface temperatures which trigger the release of cholera into the environment. Cholera risk may be exacerbated by coastal and estuarine water warming or by local flooding (Rodó et al. 2002; Lipp et al. 2002). Thus it was found that cholera risk in Bangladesh increases with the increase in sea surface temperature (Shahid 2009). Increased precipitation in the country has been also linked to increased non-cholera diarrhoea (Hashizume et al. 2007).

Bangladesh is highly prone to flooding because of its location at the confluence of the Ganges, Brahmaputra and Meghna (GBM) rivers and because of the hydro-meteorological and topographical characteristics of the GBM delta (Mirza 2002). On average, annual floods inundate around 20 per cent of the country and can reach up to 70 per cent during an extreme flood event (Mirza 2002). As a result about two-thirds of the tube-wells and all toilets have become unusable in Bangladesh (Annya et al. 2010). During floods water supply and sanitation condition becomes severely disrupted and allows the spread of various water-borne diseases.

Low-lying coastal regions across the world are prone to salt water intrusion due to sea-level rise (Chap. 17 and 18). In Bangladesh, the south-west coast is subject to additional drivers of salinity ingress such as 
brackish shrimp cultivation (Deb 1998) and upstream withdrawal and diversion of freshwater (Mirza 1998; Gain and Giupponi 2014). Such changes have implications for the population of the delta.

\subsection{Gender and Health}

Women, due to their role in the gendered division of labour, face more imminent health risks than men (Denton 2002). As mentioned earlier, coastal Bangladesh is particularly vulnerable to natural disasters and impacts of climate change. However, women and children are disproportionately affected by such impacts in rural coastal Bangladesh (Kapoor 2011; MoEF 2009). The gender-specific levels of control over assets, as well as roles and responsibilities in the household and society, imply distinct effects of shocks from climate and health events among men and women (Brody et al. 2008).

Globally, women and children are 14 times more likely to die than men as a result of a natural disaster (SIA 2006). In the 1991 cyclone of Bangladesh, female deaths were higher than those of men. Restrictions on women's spatial movement (social restrictions, gender-specific clothes, gendered role of caring for the young), fewer opportunities to access information on risk levels and ways to minimise risk and lack of agency with regard to decisions to evacuate have all been credited with contributing to these gender differences in mortality (Ikeda 1995). Similarly during the East Bengal cyclone of 1970, more deaths occurred in women, elderly people and children in Bangladesh (Sommer and Mosley 1972). For temperature-related mortality, gender and age-based differences have been observed across the whole country (Lindeboom et al. 2012).

Violation of women's rights becomes more prominent during disasters (Nasreen 2008). According to the World Disaster Report, women and girls are at higher risk of sexual violence, sexual exploitation and abuse, trafficking and domestic violence during natural disasters (International Federation for Red Cross and Red Crescent Societies [IFRC] 2007). Adolescent girls report especially high levels of sexual harassment and abuse in the aftermath of disasters and complain of the lack of privacy in emergency shelters (Bartlett 2008). Natural disasters also exacerbate child marriage in the coastal areas of Bangladesh; frequent flooding and river erosion means many 
families live with constant insecurity and variable poverty levels, which impact decisions about schooling and marriage for girls (HRW 2015).

Traditionally, the burden of coping with food shortages largely falls on the shoulders of women (Nasreen 2008). Both women and girls suffer more from shortages of food and economic resources in the aftermath of disasters (Neumayer and Plumper 2007). In Bangladesh, due to unequal food distribution in the family, a girl child receives 20 per cent fewer calories than a boy child (Ikeda 1995). The recent FSNSP study showed that of those who had to sleep hungry, 64 per cent were female children (up to four years old) compared to 24 per cent of male children (HKI and BIGH 2016).

Changes in seasons and climatic conditions imply that women and children in coastal areas may have to use water supplies from unsafe sources such as dirty ponds, which tend to dry up during the dry season, increasing their exposure to water-borne diseases such as diarrhoea. Furthermore, the increased time taken to fetch water may entail that young female household members are additionally required to help with household duties, increasing the likelihood of their missing school (Denton 2002). Moreover, women face respiratory problems caused by indoor pollution due to their direct contact with traditional fuels. In the event of a disaster, male children are likely to receive preferential treatment in rescue efforts (Neumayer and Plumper 2007). Vulnerability of women to certain diseases may also be high compared to men.

\subsection{Conclusion}

Bangladesh has progressed significantly in terms of family planning, food security, economic development, disaster preparedness and overall health (increased life expectancy, decreased maternal and infant mortality, etc.). However, considerable challenges remain for the coastal area which is highly exposed to natural disasters due its geophysical setting and social context. Cyclones, tidal flooding, coastal erosion, salt water intrusion, change in precipitation patterns, may directly or indirectly lead to adverse health outcomes, some of which are already being observed. The coastal areas have undergone a transition of livelihoods in recent decades accompanied by land-use changes. The health and livelihoods of the delta people are intertwined and impact on one may lead to impact on the other. 
Therefore any loss or degradation of ecosystem services due to natural hazards or human induced land-use change may result in loss of livelihoods and income which may ultimately lead to worsened health and well-being. Food, water and nutritional security are other areas of concern, and thus more research needs to be carried out and interventions should be implemented. Health risks from certain non-communicable and infectious diseases are more likely to increase and thus demands extra attention from the government and health planners.

\section{References}

Ali, A.M.S. 2006. Rice to shrimp: Land use/land cover changes and soil degradation in Southwestern Bangladesh. Land Use Policy 23 (4): 421-435. https:// doi.org/10.1016/j.landusepol.2005.02.001.

Annya, C.S., A.P. Gulsan, B. Chaitee, and S. Rajib. 2010. Impact and adaptation to flood: A focus on water supply, sanitation and health problems of rural community in Bangladesh. Disaster Prevention and Management: An International Journal 19 (3): 298-313. https://doi.org/10.1108/0965 3561011052484.

Bartlett, S. 2008. Climate change and urban children: Impacts and implications for adaptation in low-and middle-income countries. Environment and Urbanization 20 (2): 501-519.

Brody, A., J. Demetriades, and E. Esplen. 2008. Gender and climate change: Mapping the linkages; a scoping study on knowledge and gaps. Brighton: Institute of Development Studies. http://siteresources.worldbank.org/ EXTSOCIALDEVELOPMENT/Resources/DFID_Gender_Climate_ Change.pdf. Accessed 20 Apr 2017.

Cash, R.A., S.R. Halder, M. Husain, M.S. Islam, F.H. Mallick, M.A. May, M. Rahman, and M.A. Rahman. 2013. Reducing the health effect of natural hazards in Bangladesh. The Lancet 382 (9910): 2094-2103. https://doi. org/10.1016/s0140-6736(13)61948-0.

Comes, M., M. Dubbert, M. Garschagen, M. Hagenlocher, R. Sabelfeld, Y.J. Lee, L. Grunewald, M. Lanzendörfer, P. Mucke, O. Neuschäfer, S. Pott, J. Post, S. Schramm, D. Schumann-Bölsche, B. Vandemeulebroecke, T. Welle, and J. Birkmann. 2016. World risk report 2016. Germany: Bündnis Entwicklung Hilft, United Nations University - Institute for Environment and Human Security. http://weltrisikobericht.de/wp-content/uploads/2016/ 08/WorldRiskReport2016.pdf. Accessed 20 Apr 2017. 
Deb, A.K. 1998. Fake blue revolution: Environmental and socio-economic impacts of shrimp culture in the coastal areas of Bangladesh. Ocean and Coastal Management 41 (1): 63-88. https://doi.org/10.1016/ S0964-5691(98)00074-X.

Denton, F. 2002. Climate change vulnerability, impacts, and adaptation: Why does gender matter? Gender and Development 10 (2): 10-20. https://doi. org/10.1080/13552070215903.

Edenhofer, O., R. Pichs-Madruga, Y. Sokona, E. Farahani, S. Kadner, K. Seyboth, ... and B. Kriemann. (2014). IPCC, 2014: Summary for policymakers. Climate Change.

Frongillo, E.A., M. de Onis, and K.M.P. Hanson. 1997. Socioeconomic and demographic factors are associated with worldwide patterns of stunting and wasting of children. Journal of Nutrition 127 (12): 2302-2309.

Gain, A.K., and C. Giupponi. 2014. Impact of the Farakka Dam on thresholds of the hydrologic flow regime in the Lower Ganges River Basin (Bangladesh). Water 6 (8): 2501-2518. https://doi.org/10.3390/w6082501.

Haque, M.A., S.S. Yamamoto, A.A. Malik, and R. Sauerborn. 2012. Households' perception of climate change and human health risks: A community perspective. Environmental Health 11 (1): 1. https://doi. org/10.1186/1476-069X-11-1.

Hashizume, M., B. Armstrong, S. Hajat, Y. Wagatsuma, A.S.G. Faruque, T. Hayashi, and D.A. Sack. 2007. Association between climate variability and hospital visits for non-cholera diarrhoea in Bangladesh: Effects and vulnerable groups. International Journal of Epidemiology 36 (5): 1030-1037. https://doi.org/10.1093/ije/dym148.

HKI, and BIGH. 2016. State of food security and nutrition in Bangladesh: 2014. Dhaka: Helen Keller International (HKI) and BRAC Institute of Global Health (BIGH).

Hoque, A.K.F., and D.K. Datta. 2005. The mangroves of Bangladesh. International Journal of Ecology and Environmental Sciences 31 (3): 245-253.

Hossain, M.S. 2001. Biological aspects of the coastal and marine environment of Bangladesh. Ocean and Coastal Management 44 (3): 261-282. https://doi. org/10.1016/S0964-5691(01)00049-7.

Houghton, J.T. 2009. Global warming: The complete briefing. 4th ed. Cambridge, UK: Cambridge University Press.

HRW. 2015. Marry before your house is swept away: Child marriage in Bangladesh. New York: Human Rights Watch (HRW). https://www.hrw.org/sites/default/ files/report_pdf/bangladesh0615_web.pdf. Accessed 20 Apr 2017. 
Ikeda, K. 1995. Gender differences in human loss and vulnerability in natural disasters: A case study from Bangladesh. Bulletin (Centre for Women's Development Studies) 2 (2): 171-193.

International Federation for Red Cross and Red Crescent Societies [IFRC]. 2007. World disaster report 2007: Focus on discrimination, Geneva. http:// www.ifrc.org/Global/Publications/disasters/WDR/WDR2007-English.pdf.

Islam, M., H. Sakakibara, M. Karim, and M. Sekine. 2011. Rural water consumption behavior: A case study in southwest coastal area, Bangladesh. Proceedings of the 2011 World Environmental and Water Resources Congress, May 22-26, Palm Springs.

Jaron, D., and O. Galal. 2009. Food security and population health and well being. Asia Pacific Journal of Clinical Nutrition 18 (4): 684-687.

Kabir, M.I., M.B. Rahman, W. Smith, M.A.F. Lusha, and A.H. Milton. 2016. Climate change and health in Bangladesh: A baseline cross-sectional survey. Global Health Action 9. https://doi.org/10.3402/Gha.V9.29609.

Kapoor, A. 2011. Engendering the climate for change: Policies and practices for gender-just adaptation. New Delhi: Alternative Futures.

Khan, A.E., A. Ireson, S. Kovats, S.K. Mojumder, A. Khusru, A. Rahman, and P. Vineis. 2011. Drinking water salinity and maternal health in Coastal Bangladesh: Implications of climate change. Environmental Health Perspectives. https://doi.org/10.1289/ehp.1002804.

Khan, A.E., P.F. Scheelbeek, A.B. Shilpi, Q. Chan, S.K. Mojumder, A. Rahman, A. Haines, and P. Vineis. 2014. Salinity in drinking water and the risk of (pre)eclampsia and gestational hypertension in coastal Bangladesh: A casecontrol study. PLoS One 9 (9): e108715. https://doi.org/10.1371/journal. pone. 0108715 .

Kramer, M.S. 1987. Determinants of low birth-weight - Methodological assessment and meta-analysis. Bulletin of the World Health Organization 65 (5): 663-737.

Lindeboom, W., N. Alam, D. Begum, and P.K. Streatfield. 2012. The association of meteorological factors and mortality in rural Bangladesh, 1983-2009. Global Health Action 5 (s1): 61-73. https://doi.org/10.3402/Gha. V5i0.19063.

Lipp, E.K., A. Huq, and R.R. Colwell. 2002. Effects of global climate on infectious disease: The cholera model. Clinical Microbiology Reviews 15 (4): 757-770. https://doi.org/10.1128/CMR.15.4.757-770.2002.

Mirza, M.M.Q. 1998. Diversion of the Ganges water at Farakka and its effects on salinity in Bangladesh. Environmental Management 22 (5): 711-722. https://doi.org/10.1007/s002679900141. 
2002. Global warming and changes in the probability of occurrence of floods in Bangladesh and implications. Global Environmental Change 12 (2): 127-138. https://doi.org/10.1016/S0959-3780(02)00002-X.

MoEF. 2009. National Adaptation Programme of Action (NAPA). Update of 2005 report. Ministry of Environment and Forests (MoEF), Government of the People's Republic of Bangladesh. http://www.climatechangecell.org.bd/ Documents/NAPA\%20october\%202009.pdf. Accessed 01 Aug 2016.

Nahar, N., Y. Blomstedt, B. Wu, I. Kandarina, L. Trisnantoro, and J. Kinsman. 2014. Increasing the provision of mental health care for vulnerable, disasteraffected people in Bangladesh. BMC Public Health 14 (1): 708. https://doi. org/10.1186/1471-2458-14-708.

Nasreen, M. 2008. Impact of climate change on food security in Bangladesh: Gender and disaster perspectives. International symposium on climate change and food cecurity in South Asia, Dhaka.

Neumayer, E., and T. Plumper. 2007. The gendered nature of natural disasters: The impact of catastrophic events on the gender gap in life expectancy, 1981-2002. Annals of the Association of American Geographers 97 (3): 551-566. https://doi.org/10.1111/j.1467-8306.2007.00563.x.

Obrist, B., N. Iteba, C. Lengeler, A. Makemba, C. Mshana, R. Nathan, S. Alba, A. Dillip, M.W. Hetzel, and I. Mayumana. 2007. Access to health care in contexts of livelihood insecurity: A framework for analysis and action. PLoS Medicine 4 (10): e308. https://doi.org/10.1371/journal.pmed.0040308.

Osmani, S.R. 1993. The entitlement approach to famine: An assessment. Working paper 107. Helsinki: UNU World Institute for Development Economics Research. https:/www.wider.unu.edu/sites/default/files/WP107.pdf.Licence 107. Accessed 20 Apr 2017.

Pomeroy, R.S., B.D. Ratner, S.J. Hall, J. Pimoljinda, and V. Vivekanandan. 2006. Coping with disaster: Rehabilitating coastal livelihoods and communities. Marine Policy 30 (6): 786-793. https://doi.org/10.1016/j. marpol.2006.02.003.

Rodó, X., M. Pascual, G. Fuchs, and A. Faruque. 2002. ENSO and cholera: A nonstationary link related to climate change? Proceedings of the National Academy of Sciences 99 (20): 12901-12906. https://doi.org/10.1073/ pnas.182203999.

Saha, K.K., E.A. Frongillo, D.S. Alam, S.E. Arifeen, L.A. Persson, and K.M. Rasmussen. 2009. Household food security is associated with growth of infants and young children in rural Bangladesh. Public Health Nutrition 12 (9): 1556-1562. https://doi.org/10.1017/S1368980009004765.

Scheelbeek, P. 2015. Hypertensive diseases in salinity prone coastal areas. $\mathrm{PhD}$ thesis, Imperial College, London. 
Shahid, S. 2009. Probable impacts of climate change on public health in Bangladesh. Asia-Pacific Journal of Public Health 22 (3): 310-319. https:// doi.org/10.1177/1010539509335499.

Shameem, M.I.M., S. Momtaz, and R. Rauscher. 2014. Vulnerability of rural livelihoods to multiple stressors: A case study from the southwest coastal region of Bangladesh. Ocean and Coastal Management 102: 79-87. https:// doi.org/10.1016/j.ocecoaman.2014.09.002.

Shultz, J.M., J. Russell, and Z. Espinel. 2005. Epidemiology of tropical cyclones: The dynamics of disaster, disease, and development. Epidemiologic Reviews 27 (1): 21-35.

SIA. 2006. Reaching out to women when disaster strikes. White paper - Updated May 2011. Philadelphia: Soroptimist International of the Americas. http:// www.soroptimist.org/whitepapers/whitepaperdocs/wpreachingwomen disaster.pdf. Accessed 20 Apr 2017.

Sommer, A., and W. Mosley. 1972. East Bengal cyclone of November, 1970: Epidemiological approach to disaster assessment. The Lancet 299 (7759): 1030-1036.

Stoch, M.B., and P.M. Smythe. 1963. Does undernutrition during infancy inhibit brain growth and subsequent intellectual development. Archives of Disease in Childhood 38 (202): 546.

Syvitski, J.P.M., A.J. Kettner, I. Overeem, E.W.H. Hutton, M.T. Hannon, G.R. Brakenridge, J. Day, C. Vorosmarty, Y. Saito, L. Giosan, and R.J. Nicholls. 2009. Sinking deltas due to human activities. Nature Geoscience 2 (10): 681-686. https://doi.org/10.1038/ngeo629.

Talukder, M.R.R., S. Rutherford, C. Huang, D. Phung, M.Z. Islam, and C. Chu. 2017. Drinking water salinity and risk of hypertension: A systematic review and meta-analysis. Archives of Environmental and Occupational Health 72 (3): 1-13. https://doi.org/10.1080/19338244.2016.1175413.

van Schendel, W. 2009. A history of Bangladesh. Cambridge, UK: Cambridge University Press.

Vineis, P., Q. Chan, and A. Khan. 2011. Climate change impacts on water salinity and health. Journal of Epidemiology and Global Health 1 (1): 5-10. https:// doi.org/10.1016/j.jegh.2011.09.001.

Yunus, M., N. Sohel, S.K. Hore, and M. Rahman. 2011. Arsenic exposure and adverse health effects: A review of recent findings from arsenic and health studies in Matlab, Bangladesh. The Kaohsiung Journal of Medical Sciences 27 (9): 371-376. https://doi.org/10.1016/j.kjms.2011.05.012. 
Open Access This chapter is licensed under the terms of the Creative Commons Attribution 4.0 International License (http://creativecommons.org/licenses/ by/4.0/), which permits use, sharing, adaptation, distribution and reproduction in any medium or format, as long as you give appropriate credit to the original author(s) and the source, provide a link to the Creative Commons license and indicate if changes were made.

The images or other third party material in this chapter are included in the chapter's Creative Commons license, unless indicated otherwise in a credit line to the material. If material is not included in the chapter's Creative Commons license and your intended use is not permitted by statutory regulation or exceeds the permitted use, you will need to obtain permission directly from the copyright holder.

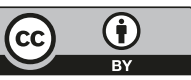

